\title{
SINO-ARABIC SCRIPT AND ARCHITECTURAL INSCRIPTIONS IN XI'AN GREAT MOSQUE, CHINA
}

Djamel Dilmi

\author{
College of Architecture, Design and Planning \\ Qassim University, KSA \\ Email Address: djamel@qec.edu.sa / \\ dilmi1@yahoo.com
}

\begin{abstract}
The Islamic art have played a significant role in the development of Muslim Chinese community in China, it was developed through time in response to cultural needs of the minority Muslim groups in China. The Islamic calligraphy was widely used in architecture, especially in interior and exterior decoration of mosques and other religious buildings. The aim of this study is to interpret the Islamic art and architecture in China through application of Sino-Arabic script on mosques and crafts produced by Muslim minority in China in relation to the Islamic civilization and Chinese civilization, in order to suggest some guidelines for the preservation of this forgotten Islamic heritage. To achieve the aim of this paper the Sino-Arabic inscriptions will be examined in order to determine their characteristics and the nature of the effects to which they have been subjected. A broad range of information was collected from various sources and through a field survey that was carried out in Xi'an Great Mosque in China. The collected information from field work will be analyzed with particular regard to the special character of Chinese Islamic art and architecture. This study is an attempt to address the important topic of Islamic calligraphy and its application on architectural buildings in China as part of issues of Islamic architectural heritage and its integration with local tradition that have been occurred in the Muslim world and it is hoped that it is going to be a significant contribution to the subject of Islamic art and architecture in China as well as revival and preservation of this forgotten heritage. Detailed conclusion will be arrived at the end and specific suggestions are intended to assist in examining the topic in depth and helping in developing guidelines for regional expansion and adaptation of Islamic art and architecture with local environmental condition to contribute more for the future of Muslim heritage and civilization.
\end{abstract}

Keywords: Sino-Arabic script, mosque, civilization, heritage

\begin{abstract}
Abstrak
Seni Islam telah berperan penting dalam perkembangan masyarakat Tionghoa Muslim di China, itu dikembangkan melalui waktu dalam menanggapi kebutuhan budaya kelompok-kelompok minoritas Muslim di Cina. Kaligrafi Islam secara luas digunakan dalam arsitektur, terutama dalam dekorasi interior dan eksterior masjid dan bangunan keagamaan lainnya. Tujuan dari penelitian ini adalah untuk menafsirkan seni Islam dan arsitektur di Cina melalui aplikasi script Sino-Arab di masjid dan kerajinan yang diproduksi oleh minoritas Muslim di Cina dalam kaitannya dengan peradaban Islam dan peradaban Cina, dalam rangka untuk menyarankan beberapa pedoman untuk pelestarian warisan Islam yang terlupakan ini. Untuk mencapai tujuan makalah ini prasasti Sino-Arab akan diperiksa untuk menentukan karakteristik dan sifat dari efek yang mereka telah menjadi sasaran. Sebuah berbagai informasi yang dikumpulkan dari berbagai sumber dan melalui survei lapangan yang dilakukan di Masjid Besar Xi'an di China. Informasi yang dikumpulkan dari kerja lapangan akan dianalisis khususnya berkaitan dengan karakter khusus seni Islam Cina dan arsitektur. Penelitian ini merupakan upaya untuk mengatasi topik penting kaligrafi Islam dan penerapannya pada bangunan arsitektur di Cina sebagai bagian dari masalah warisan arsitektur Islam dan integrasi dengan tradisi lokal yang telah terjadi di dunia Muslim dan diharapkan bahwa akan menjadi kontribusi yang signifikan terhadap subjek seni Islam dan arsitektur di Cina serta kebangkitan dan pelestarian warisan terlupakan ini. Kesimpulan rinci akan tiba di akhir dan saran-saran khusus dimaksudkan untuk membantu dalam memeriksa topik secara mendalam dan membantu dalam mengembangkan pedoman untuk ekspansi regional dan adaptasi seni Islam dan arsitektur dengan kondisi lingkungan setempat untuk memberikan kontribusi lebih untuk masa depan warisan dan peradaban Muslim.
\end{abstract}

Kata Kunci: Sino-Arabic script, masjid, peradaban, warisa

\section{Introduction}

Most of the mosques in the world include Arabic calligraphic inscriptions were participating in the ornamental program of the construction as part and partial of their interior design, as well as the façades and exterior spaces that belongs to the 
mosques where Qur'ānic verses inscribed on domes, doors or mihrābs.

Many examples of mosques around the world are showing different styles of Arabic calligraphy representing various regions of Muslim world including Arabia, Anatolia, Maghrib, Persia, Subcontinent India, South East Asia and China. The topic of Sino-Arabic script and its application on Islamic architecture in China is another medium of visual art that can be used to bring up cultural exchange and artistic interaction as well as inter-civilisations dialogue ${ }^{1}$.

\section{Research Background}

Islamic art and architecture in China is a field surrounded by controversy for both its name and are those who question the existence of an Islamic Chinese culture altogether, and consequently object to the term Islamic Chinese art and architecture. What they are really questioning thus is the identity of Muslim Chinese. As such, it is perceived as an enigma.

However, the dissemination of Islam in China articulates the integration between the Islamic and Chinese civilization. From generation to generation, Muslims in China were immensely seen with eminent figures in the history of China including military strategists, writers, poets, historians, astronomers, navigators and philosophers. The Muslim contribution in the field of medicine, politics, trade and art has been high acknowledged as the inseparable part of the diversified and heterogeneous civilization of China.

The study of epigraphy has been commented upon and evaluated by R. Ettinghausen and others ${ }^{2}$. In these evaluations, it is put forth that the importance of architectural inscriptions for the study of architectural history as well as cultural and social history. By the time the Mamluks raised the power in $1260 \mathrm{AD}$, the use of Arabic inscriptions on architectural buildings had become a traditional form of visual communication. Though the use of inscriptions on buildings is dates back to the first monument in Islam, the Dome of the Rock $(691 \mathrm{H})$, the root of Mamluks practice lie in the Fatimid tradition in Cairo and its interpretation by Ayyubids after them ${ }^{3}$ (figure 1 ).

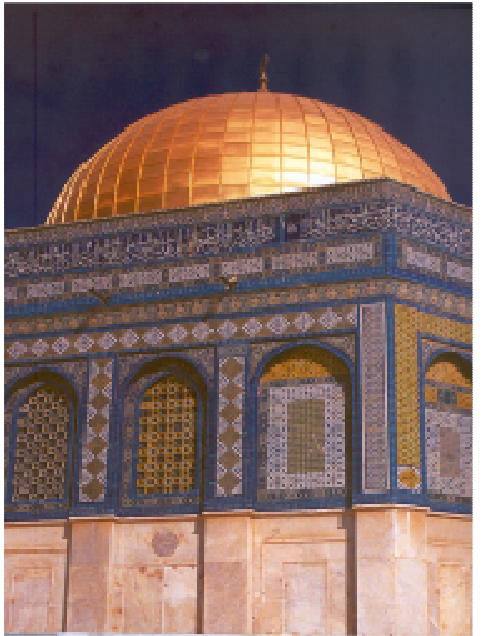

Figure 1. The first use of inscriptions on religious buildings was on the Dome of the Rock

\section{A Brief Introduction Of Xi'an Great Mosque In China}

\section{The Significance of Xi'an Great Mosque}

The Great Mosque of Xi'an as it referred to by Muslim Chinese official sources, is the oldest mosque in China and hypostyle, courtyard ever built in mosques of China. The significance of its architecture is attributed to its artistic merit, its place in the history of Muslim China, in its unique style, and its role in religious life of Muslims in Xi'an city (figure 2). In 1956, the mosque was declared as an important national historical and cultural site by the government of the People's Republic of China. The Great Mosque also is preserved under the China Conservation Unit and United Nations Educational, Scientific and Cultural Organization (UNESCO).

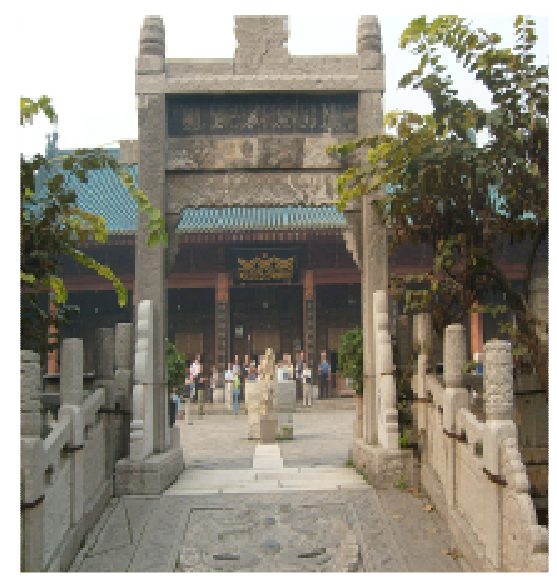

Figure 2. View of Xi'an Great Mosque that serves as a centre for religious, political and social activities of Hui Muslims 


\section{The Architecture and Layout of the Mosque}

Xi'an Great Mosque was built in elongated rectangular site in the densely populated residential area. It was first built on this site on Hua Jue Lane as early as the 700s AD during the Tang dynasty, but the current complex was laid out during the Ming Dynasty in the late 14th century. Its buildings are a fascinating fusion of Chinese and Arabic styles.

The planning layout of this mosque was based on a symmetrical and linear plan composed on four courtyards, Moon platform and prayer hall along the east-west axis. It occupies an area between 12,000 to 13,000 square meters with the build-up area of more 48 meters by 248 meters. The prayer hall was located on the main axis and each courtyard is designed as an independent space and it is separated by screen walls and gateways.

Contrasting with any other mosques, the layout of Xi'an Great Mosque has much influence of Chinese temple. It has series of courtyards in a single axis with pavilions and adapted to suit Islamic function (figure 3). However, different from other temple buildings in Chinese architecture, main axis of this mosque is aligned from the east to the west, facing Mecca.

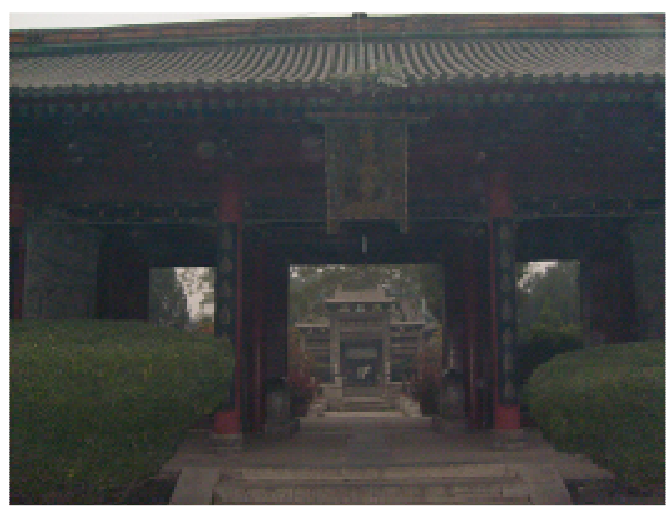

Figure 3. The influence of Chinese architectural style on $X i$ 'an Great Mosque, China shown in the components of the mosque and its roofing

\section{SURVEY AND ANALYSIS OF SINO-ARABIC SCRIPT IN XI'AN GREAT MOSQUE}

\section{The Application of Sino-Arabic Script in the Decoration of the Mosque}

There was a long tradition in the Muslim world of using Arabic calligraphic inscriptions, particularly to decorate the facades and other parts of monumental structures. The calligraphic decoration remains in many locations of the mosque internally and externally such as the prayer room, mihrāb, minbar, ablution room and courtyards.

\section{The Masterpiece of Full Text of Qur'ān Carved on Wooden Panels}

The Qur'ānic inscriptions of full text of Qur'ān carved on wooden panels along the interior walls of worship hall of Xi'an Great Mosque are a major decorative element of the mosque and are considered as a masterpiece of Islamic art in China.

The inscription started with Bismilah, surah 1 and then surah 2 followed up to surah 114 , since there is no break in the Qur'ānic text, it implies that the original idea was to have the Qur'ān itself inscribed from beginning to the end. One may add that in spite of the fact that it was not complete, it was always regarded in popular and folk account that the mosque contained the whole Qur'ān. But the fact that it displayed the full text of Qur'ān is a main difference between Xi'an Great Mosque and other old mosques of Muslim land. The carved inscription of the full Qur'ān on wooden panels gives the mosque a unique character that differentiated from other mosques of the Muslim world (figure 4).

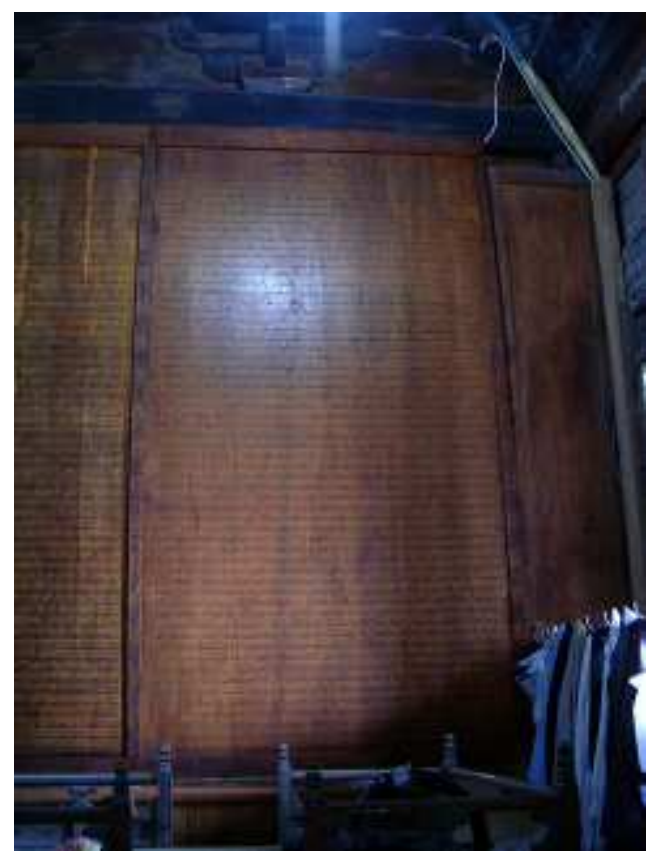

Figure 4. The full text of Qur'an is carved on wooden panels at Xian Great Mosque

\section{Location and Placement of Sino-Arabic Script Inside the Hall of Prayer}

Inside the main hall of prayer of Xi'an Great Mosque, there are many Arabic calligraphic inscriptions from Qur'ānic verses applied on wood carving combined with floral motifs 


\section{The Inscription at the central bay}

The inscriptions at the central bay are in form of couplets hang on the wooden columns of the mosque, the inscriptions are inscribed in vertical form carved on wood and highlighted in gold paintings with black background (figure 5).

The inscriptions read the Shahadah and Divine attribute of God (ninety nine names of Allah). The names are the complete 99 attributes of Allah written in vertical form. Every column contains thirteen small diamond forms inscribing the attributes on it, starts with:
1) (tr: He is Allah)
2) (tr: The infinitely Good)
3) (tr: The Merciful)
4) (tr: The King)
5) (tr: The Holy)
6) (tr: The Flawless)
7) (tr: The Faithful)
8) (tr: The Guardian)
9) (tr: The Eminent) and
10) (tr: The Compeller)

The other couplets are inscribed with respected thirteen attributes till the end of the 99 attributes of God.

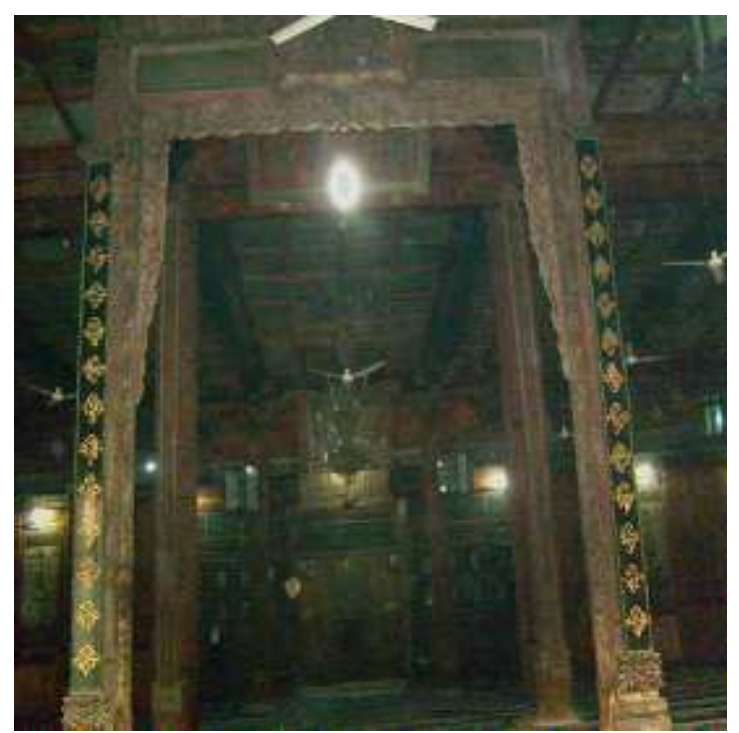

Figure 5. The calligraphic inscriptions in form of couplets hang on the pillars of central bay in Xi'an Great Mosque

\section{The Inscription at the Mihrāb Wall}

In most cases of mosques around the Muslim world the mihrāb wall is the most decorated piece, it continues to be a major and highly decorated element inside the mosque. However, the mihrāb wall of the Great Mosque of Xi'an is a master piece of wood carving using calligraphy and floral motifs, the mihrāb is in concave shape, as in all mihrābs, and is located in the qiblah wall of the mosque. The artistic technique was used in the decoration of the mihrāb wall was mainly wood carving with Arabic inscriptions as well as geometric patterns and floral motifs that form a frame around the mihrāb and also appear in the bottom part of it (figure 6). However, the interior of the niche, is divided into an upper and lower section by bands of wood carving, the upper section has alternately coloured and plain vertical triangles which meet below the apex of the arch at a lotus. The lower part is carved with floral motifs. The mihrāb wall is framed by a wooden panel carved of floral motifs integrated with two small inscriptions in two circular frames, which read which means God is Amnesty, God is forgiving.

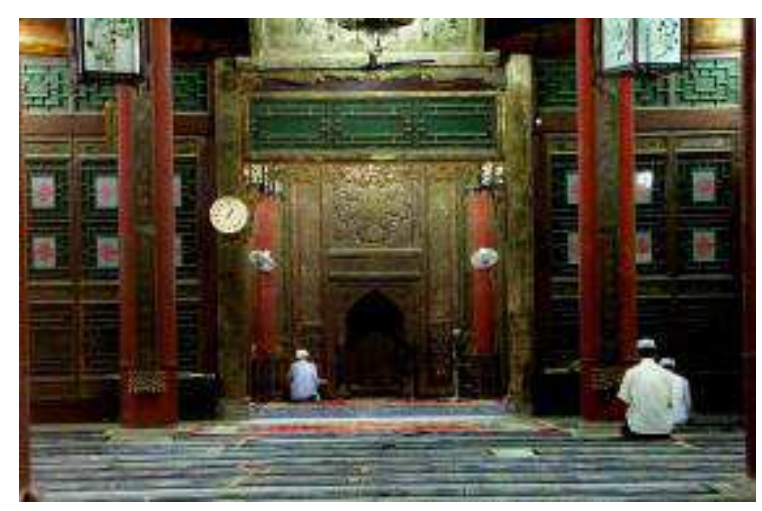

Figure 6. An Interior view of the prayer hall and its stylistic calligraphic decoration

Calligraphic inscriptions from Qur'ānic verses are inscribed on the mihrāb wall in form of bands of decoration divided into horizontal and vertical as well as well lower and upper sections. On its exterior, the mihrāb is framed by three panels of decoration with alternate floral and geometric design. At the base of the second of the three farming panels is a rectangular space on the niche inscribed with Shahadah: There is no God but Allah and Muhammad is his messenger. Another square shape above it was inscribed with one of the shortest chapters from Qur'an (al-Ikhlas):" He has no associate. The One, the eternally Besought of all" [epithets]- "He begetteth not nor was begotten, and there is none comparable unto Him" (112:3-4,). Sūrah 112, al-Ikhlās is the other text that is frequently applied in mosques around the world, which state the fundamental issues of Islam. Outside these two bands of decoration there is two bands around the mihrāb wall being inscribed with Qur'ānic verses ("We were engaged in (looking after) our 
flocks and herds, and our families: do thou then ask forgiveness for us." They say with their tongues what is not in their hearts. Say: "Who then has any power at all (to intervene) on your behalf with Allah, if His Will is to give you some loss or to give you some profit? But Allah is well acquainted with all that ye do" ( Surah 48. Victory,11).

\section{The Inscription below the Ceiling}

Sino-Arabic inscription is found on wooden plaques located originally below the ceiling of Xi'an Great Mosque (figure 7). This location of inscription is one of the major elements in the mosque. It therefore deserves special attention, some inscriptions are not legible due to the painting on the wood which is in fair condition and it needs some conservation works to highlight the inscriptions. However, the inscriptions below the ceiling is conformed by the researcher that are the attribute of God, but these inscription poses yet one more serious problem. It is very difficult to read all of them for some reasons. The first is that its location is very high up. As a result, it is difficult to read for the naked eye to see it. The second is that there are some fragments of the inscription which are now lost. The third is that the prayers hall is dim and also the darkness of the hall disturbs one's vision inside the hall to a degree that makes the some inscriptions very hard to read.

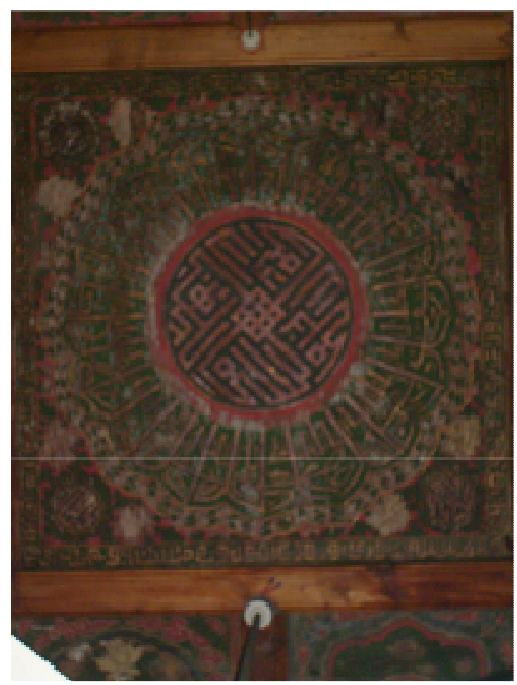

Figure 7. The inscriptions below the ceiling of the Xi'an Great Mosque

\section{Location and Placement of Sino-Arabic Script Outside the Hall of Prayer}

\section{The Inscription at Courtyards}

The complex consists of many facilities to serve the worshipers with educational, social and political activities. These facilities such as room for association meeting, room for important official guests, rooms for ablution and others for exhibitions for manuscripts and artefacts. However, all these facilities are located outside the prayers hall at the courtyards of the mosque, each facility contains calligraphic inscriptions, and the subject of these writings can be derived from different sources in Islam. (figure 8).

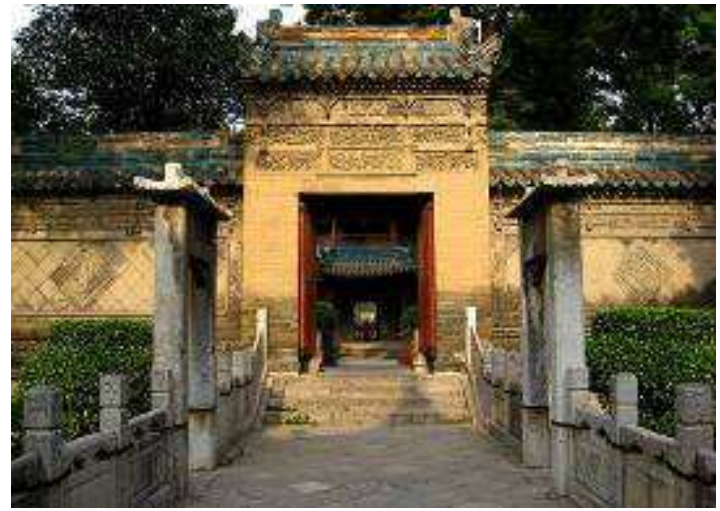

Figure 8. View of calligraphic inscriptions at courtyards which were carved on stone

\section{The Inscriptions on Stone Tablets at Memorial Hall}

The stone inscriptions in three tablets are inscribed in three languages Arabic, Persian and Chinese language. From the stone tablets indicate that Xi'an Great Mosque was originally set up in $742 \mathrm{AD}$ during the Tang Dynasty. Holding the history of 1250 years, this complex had undergone several restoration and renovation during different dynasties such as Song, Yuan, Ming and Qing dynasty (figure 9).

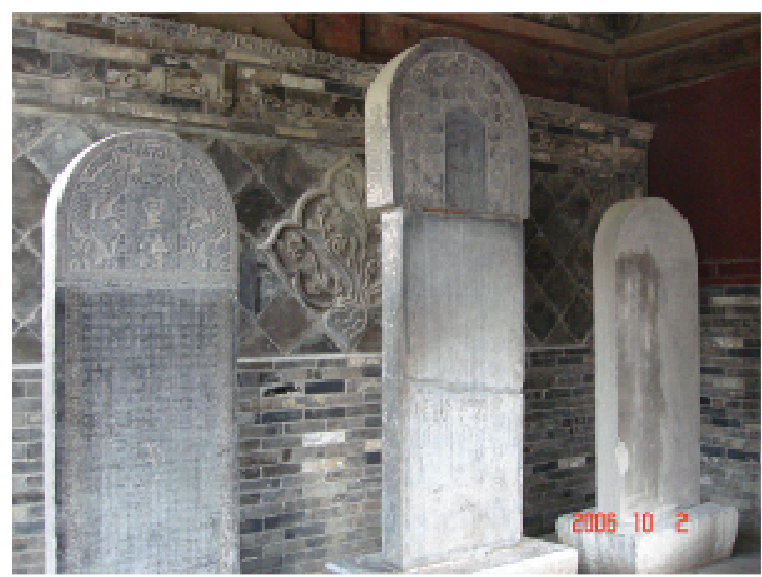

Figure 9. The carved stone inscriptions in three tablets are inscribed in three languages Arabic, Persian and Chinese language 


\section{The Inscriptions on Imperial Hall}

Sino-Arabic inscriptions are found on upper part of the doors of Imperial Hall. According to table 1, the theme of these inscriptions can be classified into: unity of Muslims and performance of Hajj (table 1).

Table 1. The Inscriptions on the Imperial Hall

\begin{tabular}{|c|c|c|}
\hline Inscription & Translation & Theme \\
\hline تفرقو اعتصموا بحبل الله جميعاو لا & $\begin{array}{l}\text { And hold fast, all together, } \\
\text { by the rope which Allah (stretches out } \\
\text { for you), and be not divided among } \\
\text { yourselves. (Ali Imran } \\
\text { 103). }\end{array}$ & Unity of Muslims \\
\hline
\end{tabular}

$\begin{aligned} \text { إلبه سبيلا الناس حج البيت لمن استطاع } & \begin{array}{l}\text { Pilgrimage there to is a } \\ \text { duty men owe to Allah, those who can } \\ \text { afford the journey.”(Ali Imran 97). }\end{array}\end{aligned}$

Hajj to Mecca afford the journey."(Ali Imran 97).

\section{The Inscriptions on Garden House}

Inscriptions are also found on the wall of Garden House which is place for resting and relaxing equipped with benches with landscape. The calligraphic inscriptions are written in form of fruit and flowers carved on stone with floral motifs which is integrated with landscape the garden (figure 10). According to table 2, the theme of these inscriptions can be classified into: remembrance of God, role of mosque, confession of faith teaching of Islam about good deeds, purification and fear of God (table 2).

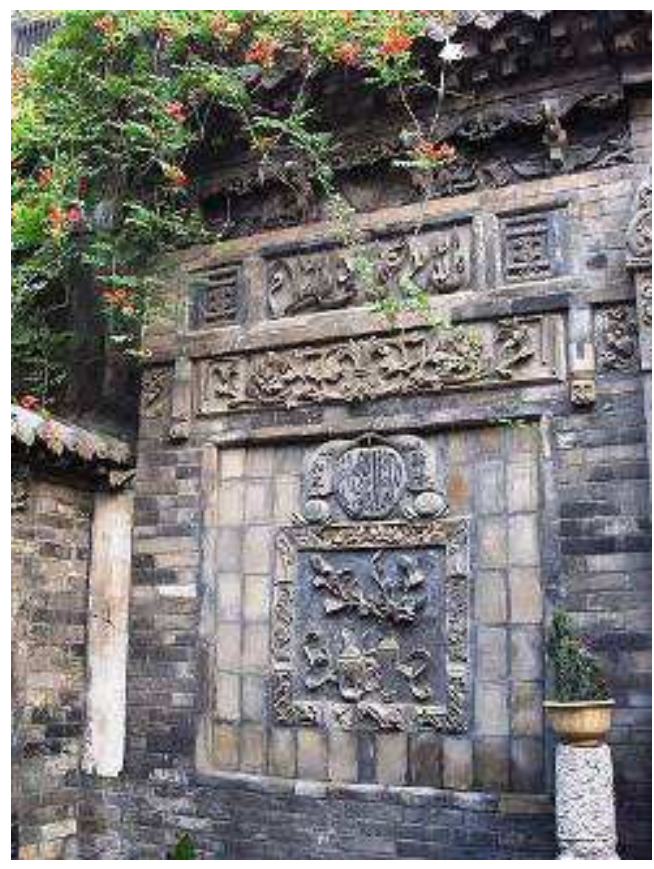

Figure 10. The calligraphic inscriptions are carved on stone in form of fruit and flowers with floral motifs.

\section{Frequent Inscriptions and Themes at Xi'an Great Mosque}

According to several studies on inscriptions on mosques, the selected themes of inscriptions at Xi'an Great Mosque are similar to other mosques around the world. Researcher elaborates the data under two separate tables. The first table contains frequent inscriptions and themes in Great mosque which are applied on the elements inside and outside the spaces of the mosque with different materials and techniques (table 3 ). Table 3 goes into deeper details about the contents of the chosen verses written in Xi'an Great Mosque. There are six common themes that can be drawn out from researcher's findings. This is in fact a very important aspect to be realized. Out of its most importance, the mosque must reflect its philosophy as the centre for Muslim unity in its essence and spirit. The most favourite theme is the Shahādah (Confession of Faith) the wide spread used in mosques around the world due to its common consideration to remind the worshippers in mosques on the Islamic faith which contained in the Shahādah. Attributes of Allah are widely used in mosque decoration. They are written in full version (ninety nine names) or in partial mainly in the prayer halls. The reason for their popularity is obvious as the essence of Islam is to accept no deity except Allah and Muslims are urged to know their God even deeper.

Similar to other mosques around the world, the inscriptions at Xi'an Great Mosque contained inscription on the mihrab, which is the full Sūrah al-Ikhlās that touches about the Oneness of Allah. This chapter is chosen for its inspirational oneness of Allah and the reason behind the popularity of this chapter in China, possibly, is the length which is short text easy to memorize and contained the is one of the most powerful Sürah's in the Qur'ān, the Sūrah completely gets rid of any 
shirk that people are committing, and moves God away from the doctrines that they have ascribed into him. The Surah deals essentially and exclusively with Tawheed.

Table 2. The Inscriptions on Garden House

\begin{tabular}{|c|c|c|}
\hline Inscription & Translation & Theme \\
\hline إن رحمة الله قريب من المحسنين & $\begin{array}{l}\text { For the Mercy of Allah is (always) } \\
\text { near to those who do goods. } \\
\text { (Surah } 7 \text { The Heights, 56). }\end{array}$ & Remembrance of Allah \\
\hline و الله يدعوا إلى دار السلام & $\begin{array}{l}\text { But Allah doth call to the Home of } \\
\text { Peace Surah } 10 . \text { Jonah, 25) }\end{array}$ & Remembrance of Allah \\
\hline إن رحمت الله قريب من المحسنين & $\begin{array}{l}\text { For the Mercy of Allah is (always) } \\
\text { near to those who do good. (Surah al- } \\
\text { Aaraf ,7. The Heights, 56). }\end{array}$ & Remembrance of Allah \\
\hline فاسجدو ا > و اعبدوا & $\begin{array}{l}\text { But fall ye down in prostration to } \\
\text { Allah, and adore (Him)! (Surah al- } \\
\text { Najm 53. The Star, 62). }\end{array}$ & Remembrance of Allah \\
\hline باب الرحمة ل & The door of Mercy & Remembrance of Allah \\
\hline باب السلامة & The door of protection & Remembrance of Allah \\
\hline اللهم إنا نسألك السلامة في الدين & $\begin{array}{l}\text { Oh Allah, we ask you in the } \\
\text { protection of religion }\end{array}$ & Remembrance of Allah \\
\hline
\end{tabular}

\section{Classification of Calligraphic Inscriptions in Xi'an Great Mosque}

The inscriptional program of Xi'an Great Mosque is unusual in that large number of Arabic calligraphic inscriptions that are inscribed. The Arabic calligraphic inscriptions that were surveyed in this mosque can be categorized into two groups: religious and non- religious. The religious inscriptions can be divided into major categories:

- The use of complete surahs or selected verse composed into one text.

- The use of prophetic saying Hadiths

- The Bismilah:" In the name of God the most Merciful and most Beneficial".

The Shahadah: "There is no God but Allah"

- The various attributes of God (99 names of Allah).

- The name of Prophet Mohammed and angels.

The non-religious inscriptions also can be divided into major categories:

- The name of the mosque

- The name of patron who contributed to the restoration of the mosque

The foundation and restoration inscriptions
Table 3. Frequent inscriptions and themes in Xi'an Great Mosque

\begin{tabular}{|c|c|c|}
\hline \\
\hline $\begin{array}{l}\text { Type of } \\
\text { inscription }\end{array}$ & $\begin{array}{c}\text { Textual } \\
\text { inscription }\end{array}$ & Theme \\
\hline Shahādah & $\begin{array}{l}\text { There is no Allah } \\
\text { but } \\
\text { Allah }\end{array}$ & $\begin{array}{l}\text { Confession } \\
\text { of } \\
\text { Faith }\end{array}$ \\
\hline $\begin{array}{l}\text { Qur'ānic } \\
\text { verse }\end{array}$ & $\begin{array}{l}\text { Sūrah 112, Ikhlās } \\
\text { (Sincere) } \\
\text { Verses } 1-4\end{array}$ & $\begin{array}{l}\text { Confession } \\
\text { of } \\
\text { Faith }\end{array}$ \\
\hline $\begin{array}{l}\text { Attributes } \\
\text { of Allah }\end{array}$ & 99 names & $\begin{array}{l}\text { Attributes } \\
\text { of Allah }\end{array}$ \\
\hline $\begin{array}{l}\text { Foundatio } \\
n \\
\text { of Mosque }\end{array}$ & $\begin{array}{l}\text { Date and } \\
\text { restoration } \\
\text { work and } \\
\text { acknowledoemen }\end{array}$ & $\begin{array}{l}\text { Foundation } \\
\text { of Mosque }\end{array}$ \\
\hline $\begin{array}{l}\text { Qur'ānic } \\
\text { verse }\end{array}$ & Sūrah, Verses & $\begin{array}{l}\text { Confession } \\
\text { of } \\
\text { Faith, }\end{array}$ \\
\hline $\begin{array}{l}\text { Prophetic } \\
\text { tradition }\end{array}$ & Hadith & $\begin{array}{l}\text { Prayers and } \\
\text { supplications }\end{array}$ \\
\hline $\begin{array}{l}\text { Names of } \\
\text { Prophet, } \\
\text { his } \\
\text { companion } \\
\text { s and }\end{array}$ & $\begin{array}{l}\text { Muhammad, Abu } \\
\text { Barker, } \\
\text { Ali, Gabriel. }\end{array}$ & $\begin{array}{l}\text { Various } \\
\text { names of } \\
\text { Prophet } \\
\text { Muhammad }\end{array}$ \\
\hline $\begin{array}{l}\text { Prayers } \\
\text { upon } \\
\text { the } \\
\text { Pronhet }\end{array}$ & $\begin{array}{l}\text { Allah' prayers } \\
\text { upon him }\end{array}$ & $\begin{array}{l}\text { Various } \\
\text { names of } \\
\text { Prophet } \\
\text { Muhammad }\end{array}$ \\
\hline
\end{tabular}




\section{RESULT EVALUATION AND SYNTHESIS}

\section{Application of Arabic Calligraphic Inscriptions on Mosques in China}

It is worthy to mention that the Arabic calligraphic inscriptions still standing on religious buildings of Muslims in China, the tendency was to employ Arabic script as a logical choice by the Muslim community whereby the main purpose was to communicate and pass the message of Islam. Consequently, legibility was a main requirement for these inscriptions and Sino-Arabic script being the most commonly used in China, answered this requirement.

However, calligraphy as one of the characteristics of Islamic art that has been used as a mean of decoration in religious buildings such as mosques, schools and houses as well in China, it had its unique form and character that influenced by Chinese culture, it was written on hang horizontal inscription boards, or formed antithetical couplets, not only to manifest the nature of religious buildings and popularized Islamic doctrine, but also to add a further dimension to the wide array of decorative patterns.

\section{The Role of Religion and Philosophy in the} Islamic Calligraphy

The outstanding quality of Sino-Arabic calligraphic inscriptions is in their variety and adaptability to the position in which they were placed in the mosque. Chosen with evident care and with regard each to its position in exterior and interior locations of the building, and to its suitable accommodation to the form of the structure or to its space provided for it, the inscriptions focus on religious expression ${ }^{4}$.

The inscriptions are so placed to instruct the mosque worshipers and visitors, to enable them to understand the Divine message ${ }^{5}$. These inscriptions are permanent reminders the Faithful that must ever be reminded to turn to Allah.

\section{Deciphering the Concept of Islamic Chinese Art and Architecture}

Islamic Chinese art and architecture is basically a product that produced for human use. It is a product for Muslim Chinese community's based on the people's way of life in which their values and organization is about being surrounded by the family members, customs, religion and a Chinese community as a whole ${ }^{6}$.
On the other hand, in the Qur'anic inscriptions Islamic calligraphic conventions are Sinicized, the proportion and informality reflecting the Chinese calligraphic preference for dynamic movement. Thus, even the mosque's most central feature in made appealing to Chinese eyes as well as Muslim sensibilities. In a sense, the mihrāb projects an image characteristic of Xi'an Great Mosque as a whole. And although the mosque does not achieve a genuine fusion of cultures, it does recognize the requirements of two great artistic traditions, one Islamic and one Chinese.

\section{Meaning of the Calligraphic Inscriptions and its Classification}

The survey lists the inscriptions and its location inside and outside the this mosque and divides them into Qur'ānic and non- Qur'ānic, which make it easier for the researcher to use it as the data for making comparison and discussing the meaning of these inscriptions (figure 11).

As a result, the beauty of inscriptions was not, however, limited to their visual impact, their content was also meant to be a source of inspiration. Naturally the architecture on which inspiration appeared affected the choice of text, or to put it in another way, the selection of particular text was made on the basis of the function of the architecture. Therefore, the meaning of inscriptions on architecture will lead the researcher to overlook the significance of holy text in Muslim's life and their faith.

\section{Integration and Transformation of Islamic Calligraphy in China}

The Muslims in China have adopted traditional Chinese architectural style in building

mosques, which is a temple-like compound with buildings around a square courtyard, and a screen wall facing the gate. The construction inside the mosque was richly ornamented with pillars and beams carved and painted, and also decorated with horizontal inscribed boards and antithetical couplets.

The first is combining the Thulth script form Islamic calligraphic style with cursive script from the Chinese calligraphic style within the same calligraphic composition ${ }^{7}$. The second is the tendency to draw the letter rather than to transcribe them, which evidently leads to a decline in the dominance of one script in its various forms. At the interpretive level, these characteristics interact and overlap in their significance or hierarchy. It remains unknown if the method of drawing the shapes of the letters instead of writing them resulted in the mixing of two styles. 


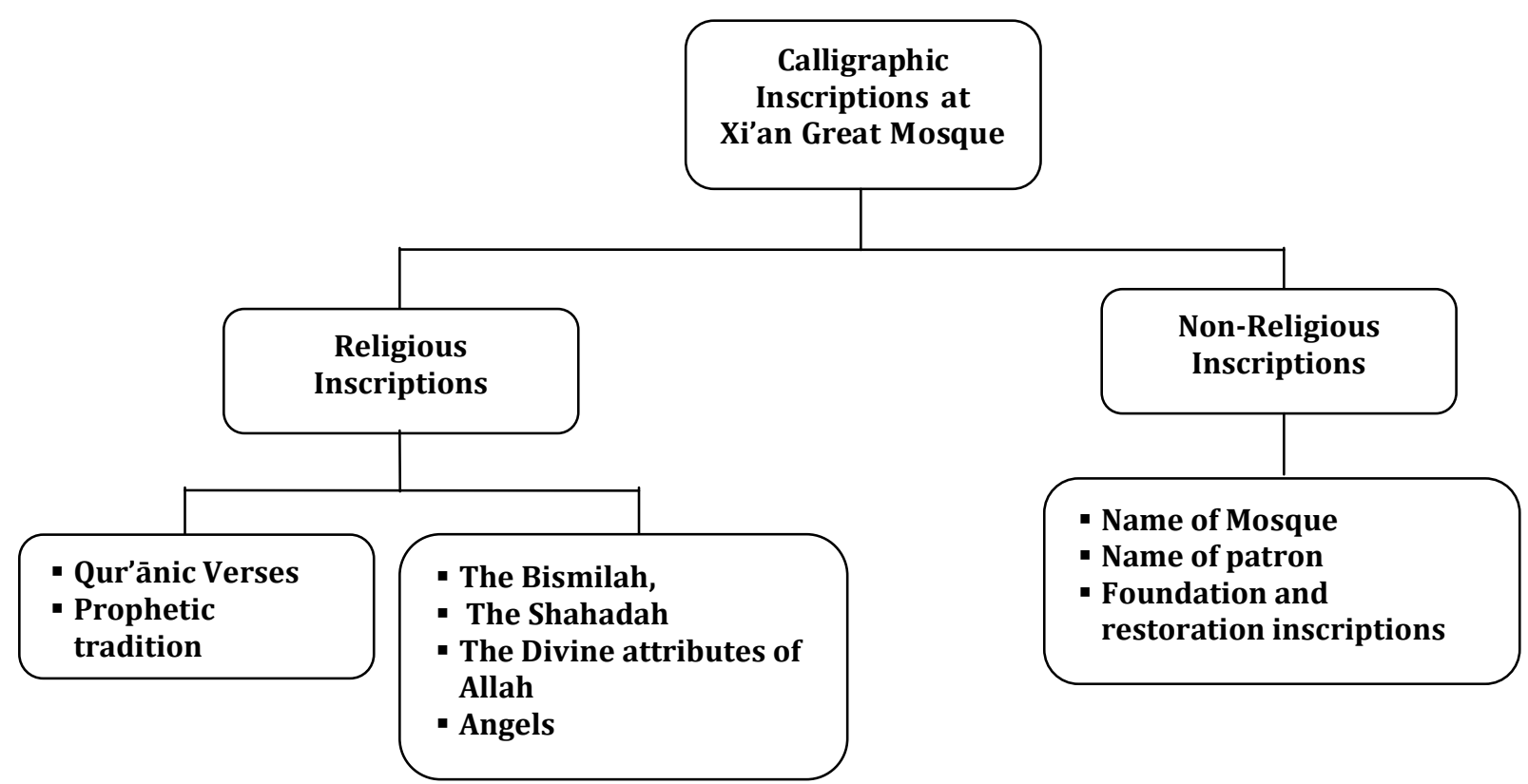

Figure 11: Classification of calligraphic inscriptions at Xi'an Great Mosque

\section{Visual Language of calligraphy in Mosques of China}

The inscriptions that found on different parts of Xi'an Great Mosque are fulfilling different purposes lead to the main functions of writing calligraphy, it is clear that these functions can be divided into categories: indicative, commemorative, semantic, iconic, and ornament. Though writing is extremely intertwined with ornament in the case of architectural inscriptions, each has its own paradigms. Writing of calligraphy deals with a subject matter that might have apparent or esoteric meanings.

The vocabulary basically deals with aesthetic concepts of calligraphy and its models of all the parts of mosque in China. It concerns such issues as styles, forms, and pattern and colour selection. The grammar, on the other hand, relates to various systems of selecting and arranging these calligraphic works into a coherent whole within the framework of Islamic concepts of educating religious teaching in the mosque.

\section{CONCLUSION \& RECOMMENDATIONS}

This research focused on the Sino-Arabic script and its application on Xi'an Great Mosque as an model of Islamic architecture in China. The future research could perhaps widen the scope by including the other Muslim ethnic groups for comparative purpose. Another issue can also be raised by some scholars in future by answering the obvious question why? What is the reason behind the absence of Islamic art in China from the international scene, particularly at this age of global communication? There might be some reasons, some of which were beyond the scope of this research.

However, it will be useful to consider some issues that are being experienced with Islamic art and architecture in China to end up with some recommendations as follows:

- Even though, this study has examined the calligraphic inscription that applied on Xi'an Great Mosque in China, established institutions specialised on conservation works are called for emergency intervention to preserve and restore this heritage which considered as a memory of Muslim Ummah.

- This research can also bridge the gape between Muslim and non Muslim and can encourage the dialogue of civilizations and cultural fusion through art and architecture.

- Islamic Chinese architecture and Sino-Arabic script are unique styles which show the beauty of Islam and the flexibility of Muslim Chinese personality that was integrated in its local environment should be encouraged in future projects and design new Islamic buildings in China. 
- Islamic architectural heritage in China is forgotten treasure needs to be preserved and to be restored as a memory of Muslim Ummah in Far East.

\section{BIBLIOGRAPHY}

[1] Zekrgoo, Amir Hossein. (2008). Dialogue of Civilizations and Cultural Fusion along The Silk Routes: An Interdisciplinary Study of The Formation of Sino-Arabic Calligraphy. Proceeding paper of conference, Maritime Communication andlslamic Culture Quanzhou, Fijian, China.

[2] Ettinghausen, Richard. (1974). Arabic Epigraphy: Communication or Symbolic Affirmation" in Near East Numismatics, Iconography, Epigraphy and History. Studies in Honour of George C Miles, Ed Dickram K, Beirut.

[3] Bierman, I A. (1998). Writing Signs, the Fatimid Public Text, University of California press.

[4] Hamzah, Abdu Rahman. (2007). The Application of Calligraphy in Mosques: Case Studies in Egypt, Turkey And Malaysia. PhD thesis, International Islamic University Malaysia.

[5] Oleg, Grabar. (1992). The Mediation of Ornament, Princeton University Press, Princeton.

[6] Luo, Xiaowei. (1994). "China" in Ed. Martin Frishman and Hasan-Uddin Khan. The Mosque: History, Architectural Development and Regional Diversity. London: Thames and Hudson

[7] Haji Noor Deen Mi, Guangjiang. (2006). Arabic Calligraphy in China: translated by R.H. AlAlusi, Season Magazine.

USA. 